\title{
The Role of Science in Postmodern Practice
}

\section{Phillip Dybicz}

\begin{abstract}
Postmodern thought offers a critique to the heavily science-based approaches of the modernist discourse. Such critiques however tend to obscure the role that science has to play in postmodern practices. The current scientific-based modernist approaches faced this similar challenge when they arose in the early 1900s. In the 1800s, social agents did not base their interventions upon scientific authority, but rather, moral authority. While scientific knowledge displaced moral knowledge as the main guide for developing treatment plans, the field of social work did not abandon moral knowledge as useless. Instead, moral knowledge was transformed into a robust code of ethics-and serves the new role of circumscribing the boundaries within which one employs scientific knowledge. The postmodern discourse calls for this same displacement to occur-it seeks to have scientific knowledge circumscribe the boundaries within which an hermeneutic inquiry driven by a critical consciousness guides social work interventions.
\end{abstract}

Keywords: Postmodern, science, hermeneutics, narrative, positivism

\section{INTRODUCTION}

In the past twenty or so years in the field of social work, postmodern thought has established a presence in academic debate and more notably, informed a number of innovative approaches to practice such as narrative therapy, the strengths perspective, and solution-focused therapy. By offering an attack upon the dominance of positivism and a scathing critique of the medical model approach to practice, some confusion has arisen over the role science has to play in the application of these innovative approaches. Some opponents (Amundson, 2001; Pilgrim, 2000; Thyer \& Myers, 1999; Thyer 2008) criticize these postmodern approaches as either being weak on employing scientific evidence or willing to ignore it completely. ${ }^{1}$ Supporters (De Shazer 1994, Weick \& Saleebey, 1998; White 2004) reply that while they do not ignore scientific evidence, they do not privilege it as the main knowledge that informs treatment goals-recognizing it as a truth, but with a small ' $t$ '. To the other side, this appears to confirm their claim that postmodern approaches are weak on science.

The scientific method's process of hypothesis testing has been translated into social work practice via the medical model (Leighninger 1987; Trattner, 1999), now commonly referred to as the problem solving approach (McMahon, 1990; Perlman, 1963; Simons \& Aigner, 1985). The phases of this approach are succinctly encapsulated by the words, "study, diagnose, treatment." Hence, with the above postmodern approaches also attacking the medical model (De Shazer et al., 2007; Saleebey, 2006b; White \& Epston, 1990), their allegiance to the scientific method appears quite weak. On the surface, it seems that there can be no clear or prominent role for science or the scientific method within postmodern practice. This poses a definite problem for the practitioner who wishes to employ one of the above postmodern practice approaches. These approaches do not call upon the practitioner to use scientific knowledge to formulate diagnoses as a road

Phillip Dybicz, Ph.D., is an Assistant Professor of Social Work in the School of Social Sciences at Keimyung University in Daegu, South Korea.

Copyright (C) 2010 Advances in Social Work Vol. 11 No. 2 (Fall 2010), 95-116 
map for the treatment plan. Instead, they seek to tap into the dreams and goals of the client (an approach that to the hard-nosed empiricist scientist appears to be overly naïve, starry-eyed, and quite simply odd). So if scientific knowledge is not used to direct the treatment plan, what role does it play in postmodern practice? The purpose of this paper to is to outline this role.

Understanding of this new role for science can be greatly facilitated by an examination of social work history. The movement from modern to postmodern practice requires a fundamental, paradigmatic shift in how we understand social work practice. Yet this is not the first time within the intellectual history of social welfare that a paradigmatic shift in understanding has occurred. Social welfare agents practicing within the 1800s operated within a much different paradigm than the one that guides modern practices today. Rather than relying upon scientific authority, these agents relied upon their moral authority to generate knowledge in which to address the ills of society (Lubove, 1965; Trattner, 1999). The scientific method requires the investigator to seek a value-free stance (as its ideal). In fact, it is seen as a way to liberate oneself from falling prey to religious dogma. On the surface, it would have seemed to some of these social agents that this new paradigm - the modern paradigm, or discourse, emphasizing the scientific method-would have no room for a role for moral knowledge to play (Leiby, 1978). And on one level this is true; within the modern discourse, applying one's moral conscience does not generate knowledge in the determination of the problem, identifying causes, and developing a plan for treatment.

Yet in its transition to the modernist practice and the scientific method, social work did not abandon moral knowledge completely. In fact, moral knowledge plays a very prominent role in guiding treatment-through a very robust code of ethics. In essence, moral knowledge maps the boundaries within which we as social workers may practice the scientific method. Benefitting from a historical record, we now know that social work's embrace of the scientific method did not result in the abandonment, or even sidelining, of moral knowledge. The paradigmatic shift that took place resulted in the transformation of the role played by moral knowledge. This same transformation, but this time in the role played by scientific knowledge, is what is called for by postmodern practice.

Hence, this paper offers a comparative historical analysis between the clash in paradigms that took place at the end of the $19^{\text {th }}$ century and early $20^{\text {th }}$ century with the clash between modern and postmodern paradigms that is taking place today. Understanding how the role played by moral knowledge was transformed from directing treatment to circumscribing the boundaries of treatment via a code of ethics will shed light on how this same transformation is called upon for scientific knowledge within postmodern practice: from directing treatment to circumscribing the boundaries of treatment. Thus the first section will outline some basic elements that comprise a discourse (Foucault 1991), or paradigm as it is being used above. Next, follows a description of the discourse operating during the 1800s which emphasized moral knowledge. This description will lead to greater understanding of the clash between this and the modern discourse and how the role for moral knowledge (as well as scientific knowledge) was transformed. Common dynamics are then outlined between this 
clash/transition and the present clash between the modern and postmodern discourses: both discourses are described, as well as their resulting clash around the concept of culture. Finally, this positions the analysis to clearly elaborate the role of science within postmodern practice.

\section{ELEMENTS OF A DISCOURSE}

Many social work histories trace the beginning of our profession to the settlement house movement and the charity organization societies of the late 1800s (Bruno, 1957; Leighninger, 1987; Lubove, 1965). And it is true that the term 'social work' arose during this time period (Trattner, 1999). Yet, the charity organization societies and the settlement house movement also mark the end of an era — an era that stretches all the way back to the early 1800s, within which, the broad conception of social welfare and overarching approaches to social welfare practice remain markedly consistent.

It is easy to look back with our present eyes and view the early charity organization society's (COS) slogan, "not alms but a friend," as a naïve engagement with the social problems of the time. As the social work profession itself was young, this naïveté is then just simply dismissed as the mark of a young profession (Thyer, 2008). Yet if one takes a careful look around at the social welfare practices of this era, one notices that a number of oddities arise when looked upon from our present standpoint. For example, why was residency (Trattner, 1999) one of the three "R"s (along with research and reform) forming the major pillars of the settlement house movement? How is it that many of the same individuals who advocated for issues such as tenement house reform and suffrage for the landless white, African-Americans, and then women, were also the ones advocating for prohibition and making prostitution illegal (Boyer, 1978; Burnett, 1968)? Odder still, how is it that the social agents involved in creating the first penitentiaries looked upon these prisons to serve as models of inspiration for the surrounding community on how to organize itself (Rothman, 2002)? Or why were social agents erecting statues in town squares or putting on city pageants - not that this is odd in itself, but odd in that they considered these practices social work (MacKaye, 1912; Patten, 1907; Robinson, 1901)?

To dismiss such practices as simply resulting from scientific naïveté is reflective more of a scientist's attempt to understand history (Thyer, 2008). A historian seeks to offer a more penetrating analysis. One historian who has offered a unique and penetrating approach in which to analyze historical events from a postmodern perspective is Michael Foucault. Within his historical studies, Foucault (1991, 1994a, 1994b) proposed the concept of a discourse: an interlacing web of linguistic structures that serves to order and legitimate knowledge. One particular discourse will gain dominance within an era, and this discourse will serve as the main paradigm for guiding one's understanding of experiences. Foucault identified a number of core elements to a discourse, and some of these will be used within the analyses that follow. The first is that a discourse always arises in response to an urgent need in society (Foucault, 1981, 1994b). Another is how human beings conceive of themselves as existing within the world (Foucault, 1981, 1994b). In addition, examining the intellectual history leading up to the era in question will further help to elucidate the workings of the discourse. 


\section{THE PRE-MODERN DISCOURSE OF THE 1800s}

\section{Urgent Need}

Borrowing a metaphor put forth by the noted historian Wiebe (1967), one can describe the various villages and towns during Colonial times as 'island communities'. Due to limits in transportation and communication, the various communities throughout Colonial America were not very integrated politically, economically, or socially. From roughly 1820 onward this would dramatically change. The advent of industrialization, urbanization, the increased mobility of labor, and technological advancements such as the railroad and telegraph all contributed toward American communities becoming integrated first at the county, then state, then national level by the end of the century (Wiebe, 1967). This integration occurred simultaneously at the political, economic, and social levels.

What alarmed social agents at the time was that the moral integration of society did not appear to accompany the rapid integration taking place on these other levels. The moral bonds of sympathy that existed within the colonial towns were not replicated within $19^{\text {th }}$ century cities, where social agents saw a rise in crime, vice, and violence. Social agents throughout this era bent their efforts at achieving this moral integration on par with the political, economic, and social integration already occurring (Addams, 1907; Chapin, 1843; Richmond, 1899). The rapid integration of society during the 1800s was an experiment in progress to these social agents-one whose outcome was unknown. In their eyes, achieving moral integration would lead to the Great Community, a lack of moral integration could easily lead to anarchy (Boyer, 1978; Quandt, 1970; Wiebe, 1967). Consequently, they bent their efforts toward achieving moral integration.

\section{Existence in the World}

During the $19^{\text {th }}$ century, people viewed themselves as existing simultaneously within two 'worlds': a transcendental world, and the natural world. Existence within a transcendental world was based in the belief that all individuals possessed a soul; this served as a major organizing influence within the human sciences (unlike today, where many people may still hold this belief but it does not organize knowledge-gathering for the human sciences). Influenced by revivalist movement in Protestant thought-The Great Awakening of the early 1700s, The Second and Third Great Awakening of the 1800s (Miller, 1965) - the soul was no longer seen as part of an hierarchical system, but rather, capable of direct communion with God. This ability of the soul to commune led to the belief that the one's soul was able to commune with other human souls. The sympathy that would necessarily arise via this communion was the model for the moral integration that the social agents sought; its existence would be evidenced by the individual's moral conduct.

At the same time, philosophical materialism had taken root starting with Hobbes and Descartes, extending through Locke, the idéologues, Hume, and Adam Smith, and culminating in the recent developments of Jeremy Bentham and John Stuart Mill,. Society viewed human beings as existing in the natural world via the notion that there existed such a thing as human nature. Yet influenced by Enlightenment thought (and 
contrary to our present notions of human nature being biologically based), human nature was anchored within a human being's ability to use reason. Human actions were seen as deriving from a moral calculus of pleasure and pain; the proper use of reason is what allowed an individual to recognize that moral pleasures (derived from one's communion with other souls) were far superior to base pleasures. Giving in to base pleasures was indicative of ignorance, or improper use on reasoning. Such actions would need to be corrected for both the benefit of the individual and society.

\section{Intellectual Thought}

In addition to the broad outlines discussed above, the impact of Jeremy Bentham and John Stuart Mill deserves further elaboration. Within social welfare, they were the dominant voice in elaborating philosophical materialism — and hence human nature-for their time period. Building upon the previous ideas of others concerning a pleasure/pain calculus to human behavior, Bentham gave this idea its fullest scope through his development of Utilitarian thought. Key aspects of his thought as they would relate to social welfare were the following: reason allows one to enjoy moral acts as the highest form of pleasure (i.e. engendering a sense of spiritual communion with others); deviant behavior is conceived as succumbing to sensual pleasures and seeking them at the expense of pursuing moral pleasures; and, most importantly, deviant behavior could be disciplined (i.e. corrected), through the imposition of an orderly routine and the separation from corrupting influences, toward a condition in which reason would once again prevail in guiding one's actions (Mack, 1969; Smith, 1997). Bentham was hailed by many as the "Newton of the moral world" for his law-like depiction of human nature (Mack, 1969). With concerns for the moral integration of society being paramount within the minds of social agents, Bentham's ideas found fertile ground and took deep root.

Mill further fleshed out Bentham's ideas through his concept of 'sanctions' (Denise, Peterfreund, \& White, 1999). Sanctions, which could be external or internal, reinforced moral behavior through a pleasure/pain calculus. External sanctions, including customs and laws of social approval/disapproval, rewarded moral behavior (e.g. acceptance, respectability) and punished immoral behavior (e.g. scorn, imprisonment). This idea of external sanctions guided practical application to Bentham's ideas on discipline. Internal sanctions, representative of proper reasoning and a communion with others, represented the pain (e.g. shame, guilt) in breaking a moral code, and conversely, the pleasure (e.g. love, benevolence) arising from following a moral code. Social agents believed that those lacking inner sanctions, evidenced by their giving into base pleasures over moral pleasures, could be disciplined into developing inner sanctions. To do so involved a program of imposing strict external sanctions as a way to facilitate the proper use of reasoning. The belief was that once the individual got enough practice using proper reasoning the artificial structure of the external sanctions could be removed; the individual would now be guided by internal sanctions after experiencing the benefits of properly using reason. 


\section{SOCIAL WORK PRACTICES IN THE 1800s}

Three broad movements arose in social welfare to address societal ills and the concern for moral integration: moral education, institutionalization, and environmentalism (Dybicz, 2006). The scope of this paper prevents a detailed listing of all the various social work practices of the era and how they reflected these movements and thus the pre-modern discourse; however, an enumeration of the practices listed earlier may suffice for our purposes here.

\section{Moral Uplift}

It was a common viewpoint among the middle class that poverty resulted from a defect of character (Mohl, 1970; Trattner, 1999). For example, in 1821 the New York Society for the Prevention of Pauperism listed six such defects as leading to poverty (intemperance, extravagance, consorting with prostitutes, idleness, gambling, and early and imprudent marriage), and even the two of three environmental factors (pawnshops, and lack of education,) reflected the notions of reason falling prey to base instincts. The final factor (indiscriminant almsgiving) was seen as merely reinforcing the six character defects.

Relief agencies would seek to morally educate the poor to help them develop internal sanctions, and hence, eliminate the moral defects causing their poverty. Robert Hartley, first head of the New York Association for Improving the Condition of the Poor (AICP) (formed in the early 1840s), saw as its mission "not merely to alleviate wretchedness, but to reform character" by enlightening the poor to "the true origins of their suffering" via "encouragement and counsel along the path to rehabilitation" (Brandt, 1942, as cited in Boyer, 1978, p. 318). And as the Baltimore AICP framed it, the visitor's goal was to help the poor reform "from sources within themselves" (Becker, 1961, p. 385). Home visitations became a central element to this approach (Boyer, 1978). The COS societies' of the 1880s "not alms but a friend" motto was a later incarnation of this approach of attempting to stimulate internal sanctions through moral uplift. They believed that solely providing material aid, while alleviating suffering, would simply feed into the underlying problem (i.e. lack of internal sanctions) - similar to how today we would hesitate to give a drug addict solely material aid without seeking to treat the underlying problem. Moral counseling was aimed at attacking the problem directly.

Moral reform was also directed at the societal level. This led to the various suffrage movements, the abolition movement, and tenement house reform. Yet with their desire to create a more moral society, it is not hard to understand that individuals involved in the above also were involved in the prohibition movement and criminalizing prostitution. Through their eyes, all of the above contributed toward improving the moral character of society.

\section{Institutionalization}

While private charities engaged in moral education efforts, the public response to societal ills was institutionalization. Institutions mushroomed up around the country during the Jacksonian era (McKelvey, 1936; Rothman, 2002), and a particular institution 
arose to address each form of deviance: the penitentiary for criminal behavior, the asylum for insanity, the almshouse for pauperism, the house of refuge for the juvenile delinquent, and the orphanage for the child pauper. Institutionalization both served to remove deviants from the corrupting influence of the environment from which they came, and placed them within a disciplined and orderly environment in which strong external sanctions existed so that they could be disciplined into learning the proper use of reasoning (i.e. internal sanctions). Their ability to re-create external sanctions reminiscent of the level that existed in the Colonial village led to the first penitentiaries being hailed as models for the community (Rothman, 2002).

The enthusiasm for institutionalization would be short lived (Gillin, 1922; Rothman, 2002). Yet despite being ineffectual, no alternatives to treatment were adopted to any significant degree. As was the case with the moral education movement, failures were ascribed to poor administration, lack of trained workers, and poor funding rather than the model itself (Rothman, 2002). It was not until the early $20^{\text {th }}$ century-when the modern discourse began to rise in prominence - that alternatives were both conceived and adopted on large scale.

\section{Environmentalism}

A common thread among all three approaches was that an environment lacking in external sanctions exerted a corrupting influence (via numerous temptations), thus inhibiting one's development of inner sanctions. The moral education movement sought to strengthen the family environment, indoctrinating the individual to resist this influence. Institutionalization simply removed the individual from the environment and placed them back when they were sufficiently trained in the use of reason. Environmentalism represented a movement directed at changing the environment itself. Beginning in the mid 1850s, a broad effort at city beautification emerged that entailed the building of parks, playgrounds, and included such things as erecting statues and hosting city pageants dramatizing the glory of the city. The idea was to create wholesome spaces within the city where the differing classes could intermingle; the beauty of nature or art would then serve to elevate a person's spirit and thus facilitate the communion of souls so desperately sought (Glaab, 1963; Peterson, 1976).

The settlement house movement represented environmentalism at its most sophisticated. The settlement house served as an extension to one's cramped tenement, which often consisted of a single room. The living room, drawing room, kitchen, etc., served as a wholesome space in which community members could congregate and intermingle. As the broad goal of this intermingling was to promote communion among all members of society, it was deemed vital that social workers (who came from the middle and upper class) live within the house and thus represent a microcosm of society within this wholesome space (Addams, 1893; Trattner, 1999). As a result of this intermingling, many practical programs for the poor were set up at the settlement house (ranging from daycare to a penny-savings bank to a meeting hall for union organizing). Settlement house workers efforts were also directed outward, taking up such causes as tenement house reform and child labor laws (Addams, 1895; Trattner, 1999). Finally, through their social survey 'research' and prolific writing, settlement house workers 
sought to communicate the plight of the poor to the middle and upper classes (Woods, 1899; Zimbalist, 1977). Believing that these members of society already possessed the social sympathy reflective of proper moral reasoning, settlement writers worked on the assumption that they simply needed to communicate the poor's plight and their audience would be motivated to act on the poor's behalf (as had been the case for themselves in their decision to join the settlement house movement).

\section{THE CLASH BETWEEN PRE-MODERN AND MODERN DISCOURSES}

The analysis of the pre-modern discourse, while highly truncated, is sufficient to move on to one of the main concerns of this paper: the clash between pre-modern and modern discourse. Within the pre-modern discourse, the social agent's base of authority rested upon moral expertise. It was because of the fact that they exhibited a high level of moral reasoning and social sympathy (evidenced by their own moral behavior) that they were well positioned to either model, educate, or discipline the development of internal sanctions in others, or direct changes in the environment which would facilitate this change.

However, during mid-century a new, competing discourse based upon science began to take root. An early indication of this is reflected in the re-organization of universities in America that took place around the 1860s and onward from being organized around concerns of philosophy (e.g. natural, moral, etc.) to being organized around specific scientific disciplines (Smith, 1997). In addition, Darwin's theory of evolution created a major stir not only in intellectual circles but within the public consciousness as well (Smith, 1997). By the late 1800s, the role of science as a means of investigation began guiding social work practices.

The COS engaged in 'scientific charity'. Within science they found the missing element for success for their moral education efforts and ascribed the failures of the previous efforts at moral education to their lack of science (Leighninger, 2000; Watson, 1922). Settlement house workers engaged in scientific research, conducting social surveys on the neighborhoods in which they lived. However as Zimbalist (1977) aptly notes, neither the COS's scientific charity nor the settlement houses' social surveys were scientific by today's standards (i.e. employing the scientific method to test hypotheses). There is good reason why this is so. The pre-modern discourse still dominated at this time. While the importance of science began to be recognized, 'science' was interpreted within the pre-modern discourse by social agents.

This necessarily led to a highly constricted view on what science entailed. As social agents rested their authority upon the proper use of moral reasoning, science naturally became an extension of that-a form of reason used to guide one's behavior: in this instance, their behavior of morally directing aid to recipients. Hence, the fundamental element of scientific investigation, hypothesis testing, was lost to these social agents (Zimabalist, 1977). In their hands, science was simply an organized form of data collection: a method to organize individual behavior on a collective level. So the COS used science to methodically collect data on all its clients; the organization of that data helped them to better direct their efforts at moral education and to wisely disperse 
material aid (Trattner, 1999; Zimbalist, 1977). Settlement house workers used science, via the social survey, to methodically collect data on the living conditions within poor environments; the organization of that data helped them to more effectively communicate the harshness of these conditions to the middle and upper classes (Young, 1949; Zimbalist, 1977). As noted earlier, the goal of this communication was to touch upon the bonds of sympathy assumed present in these individuals, and hence, get them to support changes to the environment (Young, 1949; Zimbalist, 1977).

The focus of the above scientific investigations was not one of seeking natural causal linkages - that which defines current investigations and treatment plans. Yet even within this constricted framework, science did generate knowledge-knowledge that was used to guide treatment interventions. As history has borne out, science did not simply become the latest fad in the pre-modern discourse on social welfare. Its ability to generate knowledge eventually opened up a space to do so on a much broader level via employment of the scientific method and created a growing recognition that science could provide answers to questions left unasked and unexplained in the pre-modern discourse. Eventually, this led to the modern discourse supplanting the pre-modern discourse. The transition from pre-modern to modern was not one without contention. Science's emphasis upon natural causes over moral/rational causes led many social agents at first to view science as being anti-religion and hence undermining moral knowledge (Lubove, 1965).

Benefitting from the historical record, we now know that the rise of the modern discourse in social welfare did not lead to the voiding of the importance of moral knowledge; however it did result in its displacement. Moral knowledge and expertise was translated into a very robust code of ethics. Moral expertise no longer leads to the generation of knowledge in developing a diagnosis and treatment plan; yet, its application in forms such as honoring self-determination, respecting the dignity and worth of the individual, and honoring the importance of human relationships serves to map the territorial boundaries within which scientific investigation and knowledge are applied. In this manner, moral knowledge guides social work practice. Few would argue against the notion that this is a vital role: a person who is able to expertly apply scientific knowledge but poorly applies social work values does not a good social worker make-and vice versa.

\section{THE MODERN DISCOURSE}

\section{Urgent Need}

By the early $20^{\text {th }}$ century, the integration of American society on a national level was an accepted fact. At all levels a critical mass had been achieved-political (prominence of federal reach), economic (national distribution network), and social (national, book/magazine distribution, movies, radio then TV, etc.) (Wiebe, 1967). While a Great Community may not have arisen, neither did anarchy prevail; society remained a stable force. Yet numerous social ills remained. Attention was now turned toward maintaining the proper functioning of society; at the individual level, this translated into a concern over the proper functioning of the individual. 


\section{Existence in the World}

Philosophical materialism dominates the view of human beings within the human sciences. With the emergence of the discipline of psychology, the study of mind as well as body is approached materialistically. Humans are seen as solely existing within the natural world as (bio-psycho) organisms in an (social) environment. Hence questions of human nature are framed within a debate of nature vs. nurture (Smith, 1997).

\section{Intellectual Thought}

Positivism, along with the correspondence theory of truth, serve to form the bedrock for the scientific method. Empiricism serves to further define it within this materialist framework. While the scientific method can trace its lineage all the way back to Galileo, its dominance as an organizing force within the fields of the human sciences did not arise until the late 1800 s. It would not be until the early $20^{\text {th }}$ century that it would extend its grasp to fully encompass social work practices. The impact of Darwin's theory of evolution cannot be underestimated in its contribution towards a materialist outlook on human existence. Most human behavior theories in the $20^{\text {th }}$ century revolve around concerns of adaptation and adjustment. ${ }^{2}$

\section{SOCIAL WORK PRACTICES 1900S TO PRESENT}

At the dawn of the $20^{\text {th }}$ century, social work practices underwent a dramatic transformation. By 1920, the scientific method was the dominant organizing influence for the profession (Leighninger, 1987). Training to acquire scientific expertise took the form of a rigorous academic program emphasizing scientific knowledge, theory, and modes of inquiry; later, this evolved into core elements of a curriculum resulting in degrees in social work (Leighninger, 1987).

The scientific method, with its emphasis on hypothesis testing, serves as the new organizing influence for social work practices and inquiry, broadly defining the phases of intervention as follows: "study, diagnose, treatment". The adoption of such a broadly defined approach is what served to unify the social work knowledge base in the 1950s (Kadushin, 1959; Maas, 1958). Whether through the employment of psychodynamic theory in years past (Hamilton, 1941) or ecological systems theory in the present (Germain \& Gitterman, 1980), intervention approaches follow these three phases. The scientific approach is also reflected in past calls for the development of the scientistpractitioner, the current employment of the Diagnostic and Statistical Manual, and recent calls for evidence-based practice.

\section{THE CLASH BETWEEN MODERN AND POSTMODERN DISCOURSES}

The historical record for the postmodern discourse is relatively brief, so describing the elements of this discourse poses some difficulty. However, what has been clearly established is the new front upon which this discourse has begun to challenge the dominance of the modern discourse. This new front is the concept of culture. ${ }^{3}$ Through its goal of seeking to generalize results, the scientific method inherently seeks to deemphasize the particularities of culture as they are expressed within the individual (single 
system design may be an exception to this, but it is a minor player in the social work knowledge base and does not direct movements such as evidence-based practice or person-in-environment). It is well established in philosophical circles that positivism seeks to sideline culture and history (Shimony, 1987).

For most of the $20^{\text {th }}$ century, concerns of culture were indeed sidelined, aided by the embrace of the melting pot theory (Green, 1999). Scientific theories and evidence were most important in guiding social work practices. Whether psychodynamic (e.g. Freud), humanist (e.g. Erikson), behaviorist (e.g. Bandura), or transcendental (e.g. Maslow), theory was seen as applicable to all human beings. Sociological theory was no different. Tools such as the Diagnostic and Statistical Manual and calls for evidence-based practice still emphasize generalizability over particularity when viewing human beings.

Yet from the 1970s onward, concerns of culture in guiding social work interventions have gained in prominence. Various human behavior theory textbooks now include a caveat when discussing most modernist theories, stating that they contain a Western, male, and heterosexual bias (Greene, 2008; Healy, 2005; Robbins, Chaterjee, \& Canda, 2006). Others (Green, 1999; Livingston et al., 2008; Wong et al. 2003) have noted the role of the scientific method and the generalizing of results as contributing factors to this bias. The importance of this movement in respecting culture is reflected by the wide acceptance and recognition of the need to foster cultural competency, to the point that it has become an ethical mandate (NASW, 1999) for directing social work practice.

\section{The Modern Discourse and Culture}

Culture-and hence cultural competency-seeks expression within both the modern and postmodern discourse. Yet as was the case with science in the late 1800s, the reigning discourse is only able to provide a highly constricted expression to the concept. The move to express culture and cultural competency within the modern discourse is one of incorporating it within the scientific method (just as 'science' was incorporated into the proper use of reason within the pre-modern discourse) via the focus on correcting deviance from a norm. Culture is typically conceptualized as "norms of conduct, beliefs, values, and skills” (Lum, 2007, p. 4). As such, culture becomes a form of technical knowledge: either an additional variable to consider when determining causal mechanisms or the recognition that an alternative norm may exist.

Consequently, most models on cultural competency have a strong focus upon knowledge acquisition and skill development particular to various cultural subgroups (Lum, 2007; Pedersen, 1994; Rothman, 2008). Yet significant shortfalls have surfaced with this scientific approach and these same authors have felt a need to shore up their models by adding additional, nonscientific elements. One dynamic illustrative of the this dilemma is that there is now a social work value-respecting diversity-that is doing more than just simply mapping the boundaries within which to apply the scientific method. It is generating knowledge used to develop diagnoses and treatment plans, the role heretofore assigned to science and the scientific method. Hence, as these models begin to drift from their scientific base, elements that require a critical consciousness are embraced such as, self awareness of one's own biases, reflective learning, and 
recognizing the construction of 'multiple' identities of the client (Lum, 2007; Pedersen, 1994; Rothman, 2008).

\section{The Postmodern Discourse and Culture}

Another model for cultural competency (Ramsey \& Latting, 2005) has been proposed that avoids the above-mentioned issue. Rather than viewing cultural competency as stemming from the acquisition of cultural technical knowledge, it is viewed as stemming from the employment of a critical consciousness. Abilities such as reflecting upon self, relationships, and context comprise the model. ${ }^{4}$

Within such a linguistic paradigm, culture is much more than simply technical knowledge- a description of norms for a population. Culture is a world-making process that serves to delimit one's unique being-in-the-world. This view of culture is more reflective of the German notion of kulture, dating back in intellectual thought to Herder (2002/1765-1797) and Goethe (1987/1811-1822). Culture in this manner is something that contributes towards defining one's spirit, as in one's essence of being. Culture's expression is highly contextual and particularistic. To properly understand the influence of culture upon one's essence of being, one must engage in a hermeneutic-driven inquiry.

This approach of a hermeneutic-driven inquiry is exactly what drives knowledge generation within postmodern practice. With its emphasis on values and meaning, a hermeneutic inquiry fits hand in glove with a process yielding knowledge generation via employing social work values—such as respect for diversity. ${ }^{5}$ Yet the idea of kulture takes on a much more expansive aspect in terms of encompassing social work values. Postmodern practice is highly value-driven; by engaging in hermeneutic inquiry these values generate knowledge. So for example, honoring self-determination is now a knowledge generating process. Asking clients to define their dreams and goals generates knowledge regarding the direction of their treatment plans. Respecting the dignity and worth of the clients is translated into efforts into understanding and respecting their being-in-the world, or identity (Brubaker \& Wright, 2006; White 2007). A client's identity is seen as anchored in narrative; one's dreams and goals serve to generate knowledge regarding this identity (De Jong \& Berg, 2008; McIntosh, \& McKeganey, 2000; Saleebey, 2006a). Honoring the importance of human relationships also generates knowledge. Via engaging in the process of mimesis (Dybicz, in press), the client is able to build a counterstory which serves to redefine his/her identity. Within the client-social worker relationship, the social worker is able to reflect back to the client "I see you this way too," hence, generating knowledge within the social construction process that serves to reinforce this counterstory and new identity (De Jong \& Berg, 2008; Saleebey, 2006a, White \& Epston, 1990).

The hermeneutic inquiry that is able to grasp this expansive notion of kulture does not rest upon expertise in the scientific method. Rather, it depends upon expertise in employing a critical consciousness, an understanding of how power filtrates and circulates within linguistic structures, supporting some narratives over others in such a way that in some instances they serve to diminish the client's essence, or being-in-theworld. The collaborative relationship that the social worker engages in with the client is 
an endeavor aimed at consciousness-raising. This starts with recognizing one's own learned biases and how they may interfere with one's ability to understand the client's being-in-the-world, or essence. This is then followed by the social worker adopting the role of editor via asking the client questions that serve to stimulate reflection upon oppressive narratives at work in the client's life. Thus the watchwords for such a process might be described as "question (the oppressive narrative), generate (a counterstory), and solidify (the counterstory or life-enhancing narrative)." This is a marked departure from the "study, diagnose, treatment" approach of the modern discourse. Yet, this does not mean that there is no role at all for the scientific method in the helping situation.

\section{POSTMODERN PRACTICE AND THE ROLE OF SCIENCE}

When the pre-modern and modern discourses clashed upon the battlefront of science, eventually the modern approach based upon the scientific method won out. Yet moral knowledge was not trivialized or sidelined; it was translated into a robust code of ethics. This moral knowledge circumscribed the boundaries within which the scientific method could be legitimately employed. Within the clash between modern and postmodern discourses upon the battlefront of culture, postmodern practice calls for this dynamic to repeat itself. Within postmodern practices, a hermeneutic-driven inquiry displaces a scientific method based inquiry as the dominant form of knowledge generation. This does not call for scientific knowledge to be trivialized or sidelined; rather, its place is to circumscribe the boundaries within which an hermeneutic inquiry can be legitimately employed.

Michael White (White \& Epston, 1990) provides an excellent example of this dynamic in his work in family therapy. When discussing his technique of 'externalizing the problem', he breaks it down into two steps. The first step is described as 'mapping the influence of the problem'. In this step, he employs what basically amounts to ecological systems theory to describe the impact that the presenting problem has had among the various family members. Yet this knowledge is not used to form a diagnosis and develop a treatment plan; rather, it circumscribes the boundaries for step two, which involves a hermeneutic inquiry. He describes step two as 'mapping the influence of persons'. This step involves focusing upon the clients' personal agency in mapping "their influence and the influence of their relationships in the 'life' of the problem" (p. 45). From this process, knowledge is created contributing toward a new narrative or counterstory which attacks the narrative diminishing their identity-their essence-by reinforcing their personal agency and empowering their efforts in forming a more positive identity formation.

Empirical observation (and theory that is used to guide it, such as ecological systems theory) is the means by which a scientific approach seeks to accurately capture the properties of an object or organism and how it reacts to other objects or organisms in the environment. Within the modernist discourse, the description of such properties and causal linkages represent reality-a description of the existence of the object. Postmodern approaches are based upon a phenomenological view of the world. As such, reality is made up not simply of objects and organisms but rather phenomena. A phenomenon is considered to comprise not only an existence, but also an essence. Within a phenomenon, the essence serves to organize the existing properties, emphasizing some over others. 
When speaking of humans, this essence may be thought of as one's individual identity. Thus, as briefly described earlier, postmodern approaches seek to affect change by targeting the essence of the phenomenon rather than its existence. Yet an accurate description of the existence of the phenomenon still plays a vital role. Science provides this description in a very robust way. The better the description, the better one's 'territory' is mapped out. This paves the way for a successful hermeneutic inquiry that seeks to understand the essence of the phenomenon in relation to this existence.

For example, as noted above, White (White \& Epston, 1990) applies systems theory. In the case study of Nick, White uses ecological systems theory to map the influence that Nick's encopresis has had on his life at home and at school (i.e. to accurately capture the existence of the encopresis in Nick's life). But rather than using this information diagnostically (i.e. attacking the problem directly), White uses it as a map in which to search for Nick's strengths and successes as they relate to the problem, hence step two: "mapping the influence of persons." The more detailed the map of the problem, the greater direction and specificity arises for questions geared towards uncovering these strengths and successes (i.e., the many possibilities in which Nick has already triumphed over the problem). The gained awareness of these strengths and successes represents the conscious-raising that is sought.

Of important note is the following: these strengths and successes are always in relation to the presenting problem. The context of the helping relationship will always speak to a presenting problem, challenge, or concern of the client. When the sole focus is upon the existence of this challenge in the client's life and the essence is ignored, the individuality of the client is lost and he/she becomes viewed categorically by the challenge itself (e.g., pregnant teenager). Not only does such an approach carry the danger of social control occurring, but it also undercuts the worth of the individual by painting him/her as "abnormal”, "broken”, or "dysfunctional:" they are someone that needs to be fixed (otherwise one would not need to visit a social worker). Yet, one cannot focus solely on the client's identity (i.e. essence) and ignore the existence of the challenge. If Nicole is a pregnant teen who has decided to keep her baby, the existence of her pregnancy is not something that can be conveniently ignored. Scientific knowledge tells us that she will need prenatal care, economic support, and perhaps some parenting classes. Do we attack the challenge directly and provide all of the above because she is an "at risk" mother? Or, do we plug into her dream of wanting to be a good mother, recognize the capacities she has already displayed in this endeavor, and then provide the above as the means to help her further realize her dream of being a good mom? If Nicole is supported in developing the image of herself as a good mom, her present and future actions will be tied to this image as she attempts to maintain her dream of being a good mom. Scientific knowledge of her situation not only provides a map within which to explore for her strengths and successes related to various parental challenges, but it also provides information and advice to help her fulfill her dream of being a good mom.

\section{CONCLUSION}

The paradigmatic shift required to successfully employ postmodern practices has profound implications for the practitioner. Fundamentally, it requires the practitioner to 
move from viewing interventions as an endeavor at problem-solving to viewing them as endeavors at consciousness-raising. Within a problem-solving approach to practice, scientific knowledge takes center stage as the means to arrive at solutions to the life problems faced by clients. Within postmodern practices, a critical consciousness is the main expertise brought by the social worker as the means to assist the client in generating solutions to his/her life problems. This necessarily creates a new role for scientific knowledge - that of circumscribing the boundaries within which the consciousnessraising will take place. Respect for the insights of science regarding the well-being of the client remains, but this knowledge is simply used in a new role, one that is still vital to successful social work practice (just as our present code of ethics is essential to modernist practice).

Scientific knowledge performs the vital role of mapping out the influence the problem has had or will likely have on the life of the client. This is a necessary first step in the creation of the map that is the goal of the intervention: mapping the influence of the client on the life of the problem. These two steps can be seen as representative of a postmodern dialectical process. Science provides the thesis in step one. This allows for an antithesis to emerge in step two. But rather than seeking a simple synthesis, as Gadamer (1999) notes, these two steps open up a dialogical process within which many possibilities can be explored. The properties of existence are never denied, but many possibilities of essence are explored, with the best possibility being the one that best captures the uniqueness of the client's lived experiences by promoting a positive identity of the client. This dialectical inquiry is what comprises the consciousness-raising effort.

Hence, a new role and conception of culture also takes place, one which places culture center stage during the helping process. Within postmodern practice, culture represents much more than simply the norms of a population group. Culture is the bedrock of a world-making process (the social construction of reality), a process that emphasizes the uniqueness of the individual within particular contexts. Understanding

culture in this manner requires an hermeneutic inquiry, an inquiry in which application of values serves to generate knowledge toward intervention strategies. A critical consciousness on the part of the social worker is what serves to guide the application of these values to collaboratively generate and then secure more life-enhancing possibilities for the client.

\section{References}

Addams, J. (1893). The subjective value of a social settlement. In H. C. Adams (Ed.), Philanthropy and social progress (pp. 1-26). New York: Thomas Y. Crowell

Addams, J. (1895). The settlement as a factor in the labor movement. In L. Pacey (Ed.), Readings in the development of settlement work (pp. 29-40). Freeport, NY: Books for Libraries Press.

Addams, J. (1907). Public recreation and social morality. Charities and Commons, 18, 492-494. 
Amundson, J. (2001). Why narrative therapy need not fear science and "other" things. Journal of Family Therapy, 23, 175-188. doi: 10.1111/1467-6427.00177.

Becker, D. (1961). The visitor to the New York City poor, 1843-1920. Social Service Review, 35, 372-387.

Boyer, P. S. (1978). Urban masses and moral order in America, 1820-1920. Cambridge, MA: Harvard University Press.

Bridge, T., Massie, E., \& Mills, C. (2008) Prioritizing cultural competence in the implementation of an evidence-based practice model. Children and Youth Services Review, 30, 1111-1118. doi: 10.1016/j.childyouth.2008.02.005.

Bruno, F. (1957). Trends in social work 1874-1956. New York: Columbia University Press.

Burnett, C. (1968). Five for freedom: Lucretia Mott, Elizabeth Cady Station, Lucy Stone, Susan B. Anthony, Carrie Chapman Catt. New York: Greenwood Press.

Brubaker, S., \& Wright, C. (2006). Identity transformation and family caregiving: Narratives of African-American teen mothers. Journal of Marriage and Family, 68, 1214-1228.

Chapin, E. (1843). Moral aspects of city life. New York: Baker and Taylor.

De Jong, P., \& Berg, I. K. (2008). Interviewing for solutions ( $3^{\text {rd }}$ ed.). Belmont, CA: Thomas Higher Education.

Denise, T., Peterfreund, S., \& White, N. (1999). Great traditions in ethics ( $9^{\text {th }}$ ed.). New York: Wadsworth.

De Shazer, S. (1994). Words were originally magic. New York: W. W. Norton \& Co.

De Shazer, S., \& Berg, I. K. (1992). Doing therapy: A post-structural re-vision. Journal of Marital and Family Therapy, 18, 71-81. Retrieved from Social Service Abstracts database.

De Shazer, S., Dolan, Y., Korman, H., Trepper, T., McCollum, E., \& Berg, I. K. (2007). More than miracles: The state of the art of solution-focused therapy. Binghamton, NY: Haworth Press.

Dybicz, P. (2006). A genealogy of the good: An examination of the discourse on social welfare from poor laws to strengths perspective. Ph.D. dissertation, The University of Kansas, United States -- Kansas. (Publication No. AAT 3217191).

Dybicz, P. (2010). Mimesis: linking postmodern theory to human behavior. Journal of Social Work Education, 46, 341-355. doi: 10.5175.

Foucault, M. (1981). Power-knowledge: Selected interviews \& other writings 1972-1977. New York: Pantheon Books. 
Foucault, M. (1991). Discipline \& punish: The birth of the prison. (Vintage Books, $2^{\text {nd }}$ ed., A. Sheridan, Trans.). New York: Vintage Books. (Original work published 1975).

Foucault, M. (1994a). The birth of the clinic: An archaeology of medical perception. (Vintage Books ed., A. Sheridan Smith, Trans.). New York: Vintage Books. (Original work published 1963).

Foucault, M. (1994b). The order of things: An archaeology of the human sciences. (Vintage Books ed.). New York: Vintage Books. (Original work published 1966).

Friere, P. (1997) Pedagogy of the heart (D. Macedo Trans.). New York: Continuum.

Friere, P. (2000). Pedagogy of the oppressed (30 ${ }^{\text {th }}$ anniversary ed.) (M. B. Ramos Trans.). New York: Continuum. (Originally published 1970).

Gadamer, H. G. (1999). Truth and method ( $2^{\text {nd }}$ ed.). (J. Weinsheimer \& D. G. Marshall Trans.) New York: The Continuum Publishing Company. (Original work published 1960).

Germain, C. (1970). Casework and science: A historical encounter. In R. Roberts \& R. Nee's (Eds.), Theories of social casework (pp. 3-32). Chicago: University of Chicago Press.

Germain, C., \& Gitterman, A. (1980). The life model of social work practice. New York: Columbia University Press.

Gillin, J. (1922). Poverty and dependency: Their relief and prevention. New York: The Century Co.

Glaab, C. (1963). The American city: A documentary history. Homewood, IL: Dorsey Press.

Goethe, J. (1987). From my life: Poetry and truth (parts one to four). (R. Heitner \& T. Saine Trans.) (T. Saine \& J. Sammons, Eds.). Princeton, NJ: Princeton University Press. (Original works published 1811-1822).

Green, J. (1999). Cultural awareness in the human services: A multi-ethnic approach $3^{\text {rd }}$ ed.). Boston: Allyn \& Bacon.

Greene, R. (Ed.). (2008). Human behavior theory \& social work practice ( $3^{\text {rd }}$ ed.). New Brunswick, NJ: Transaction.

Guerra, N., \& Lyndee, K. (2008). How culture impacts the dissemination and implementation of innovation: A case study of the Families and Schools Together Program (FAST) for preventing violence with immigrant Latino youth. American Journal of Community Psychology, 41, 304-313. doi: 10.1007/s10464-008-9161-4.

Hall, R. (2003). The hegemony of Eurocentrism in social work practice: From race to culture as ecological perspective vis-a-vis Southeast Asian populations. The Indian Journal of Social Work, 64, 418-431.

Hamilton, G. (1941). The underlying philosophy of social casework. Family, 23, 139-48. 
Healy, K. (2005). Social work theories in context. New York: Palgrave McMillan.

Heidegger, M. (1962). Being and time. (J. Macquarrie \& E. Robinson Trans.). New York: Harper and Row. (Original work published 1927).

Herder, J. (2002). Herder: Philosophical writings. (M. Forster Ed. and Trans.). New York: Cambridge University Press (Original works published 1765-1797).

Kadushin, A. (1959). The knowledge base of social work. In A. Kahn (Ed.), Issues in American social work (pp. 39-79). New York: Columbia University Press.

Leiby, J. (1978). A history of social welfare and social work in the United States. New York: Columbia University Press.

Leighninger, L. (1987). Social work: Search for identity. New York: Greenwood Press.

Leighninger, L (2000). Creating a new profession: The beginnings of social work education in the United States. Alexandria, VA: Council on Social Work Education.

Livingston, J., Holley, J., Eaton, S., Cliette, G., Savoy, M., \& Smith, N. (2008). Cultural competence in mental health practice. Best Practices in Mental Health, 4(2), 1-14. Retrieved from Social Service Abstracts database.

Lubove, R. (1965). The professional altruist: The emergence of social work as a career, 1880-1930. Cambridge, MA: Harvard University Press.

Lum, D. (2007). Culturally competent practice: A framework for understanding diverse groups and justice issues ( $3^{\text {rd }}$ ed.). Belmont, CA: Thomson Higher Education

MacKaye, P. (1912). The civic theatre in relation to the redemption of leisure. New York: Mitchell Kennerley.

McIntosh, J., \& McKeganey, N. (2000). Addicts' narratives of recovery from drug use: Constructing a non-addict identity. Social Science \& Medicine, 50, 1501-1510.

McKelvey, B. (1936). American prisons: A study in American social history prior to 1915. Chicago: University of Chicago Press.

McMahon, M. (1990). The general method of social work practice: A problem solving approach ( $3^{\text {rd }}$ ed.). Upper Saddle River, NJ: Prentice Hall.

Maas, H. (1958). Social casework. In W. Friedlander (Ed.), Concepts and methods of social work (pp. 15-115). Englewood Cliffs, NJ: Prentice-Hall.

Mack, M. (1969). A Bentham reader. New York: Pegasus.

Miller, P., \& American Council of Learned Societies. (1965). The life of the mind in America from the Revolution to the Civil War: Books one through three. New York: Harcourt Brace Javonovich.

Mohl, R. (1970). Humanitarianism in the preindustrial city: The New York Society for the Prevention of Pauperism, 1817-1823. Journal of American History, 57, 576-599. 
NASW. (1999). Code of ethics of the national association of social workers. Washington, DC: NASW press.

NASW. (2001). NASW standards for cultural competence in social work practice. Washington, DC: NASW press.

Patten, S. (1907). The new basis of civilization. New York: Macmillan.

Pederson, P. (1994). A handbook for developing multicultural awareness ( $2^{\text {nd }}$ ed.). Alexandria, VA: American Counseling Association.

Perlman, H. (1963). Social casework: A problem-solving approach. Chicago: University of Chicago Press.

Peterson, J. (1976). The city beautiful movement: Forgotten origins and lost meanings. Journal of Urban History, 2, 415-434.

Quandt, J. (1970). From small town to great community: The social thought of progressive intellectuals. New Brunswick, NJ: Rutgers University Press.

Ramsey, V., \& Latting, J. (2005). A typology of intergroup competencies. The Journal of Applied Behavioral Science, 41, 265-84. doi: 10.1177/0021886305277974.

Rapp, C. A., \& Goscha, R. J. (2006). The strengths model: Case management with people with psychiatric disabilities. Oxford: Oxford University Press.

Ricœur, P. (1984-88). Time and narrative (vol. 1-3). Chicago: University of Chicago Press.

Richmond, M. (1899). Friendly visiting among the poor: A handbook for charity workers. New York: Macmillan.

Robbins, S. P., Chatterjee, P., \& Canda, E. R. (2006). Contemporary human behavior theory: a critical perspective for social work. Boston: Pearson.

Robinson, C. (1901). The improvement of towns and cities. New York: G. P. Putnam's Sons.

Rothman, D. (2002). The discovery of the asylum (Revised edition). Piscataway, NJ: Aldine Transaction.

Rothman, J. (2008). Cultural competence in process and practice. New York: Pearson.

Saleebey, D. (Ed.). (2006a). The strengths perspective in social work practice $\left(4^{\text {th }} \mathrm{ed}\right.$.). Boston: Pearson/Allyn and Bacon.

Saleebey, D. (2006b). Introduction: Power in the people. In D. Saleebey’s (Ed.) The strengths perspective in social work practice ( $4^{\text {th }}$ ed., pp. 1-23). Boston: Pearson/Allyn and Bacon.

Shimony, A. (1987). Introduction. In A. Shimony \& D. Nails (Eds.), Naturalistic epistemology: A symposium of two decades (pp. 1-13). Boston Studies in the Philosophy of Science, v. 100. Boston: D. Reidel Publishing Company. 
Simons, R., \& Aigner, S. (1985). Practice principles: A problem-solving approach to social work. New York: Macmillan.

Smith, R., (1997). The Norton history of the human sciences. New York: W.W. Norton.

Thyer, B., \& Myers, L. (1999). On science, antiscience, and the client's right to effective treatment. Social Work, 44, 501-504.

Thyer, B. (2008). The quest for evidence-based practice?: We are all positivists! Research on Social Work Practice, 18, 339-345. doi: 10.1177/1049731507313998.

Trattner, W. I. (1999). From poor law to welfare state: A history of social welfare in America ( $6^{\text {th }}$ ed.). New York: The Free Press.

Pilgrim, D. (2000). The real problem for postmodernism. Journal of Family Therapy, 22, 6-28.

Wainberg, M., McKinnon, K., Mattos, P., Pinto, D., Mann, C., de Oliviera, C., et al. (2007). A model for adapting evidence-based behavioral interventions to a new culture: HIV prevention for psychiatric patients in Rio de Janeiro, Brazil. AIDS and Behavior, 11, 872-883. doi: 10.1007/s10461-006-9181-8.

Watson, F. (1922). The charity organization movement in the United States. New York: Macmillan.

Weick, A., \& Saleebey, D. (1998). Postmodern perspectives for social work. Social Thought: Journal of Religion in the Social Services, 18, 21-40. Retrieved from ASSIA.

Westfall, R. (1978). The construction of modern science: Mechanisms and mechanics. New York: Cambridge University Press.

White, M., \& Epston, D. (1990). Narrative means to therapeutic ends. New York: Norton.

White, M. (2004). Folk psychology and narrative practices. In L. Angus \& J. McLeod (Eds.), The handbook of narrative and psychotherapy: Practice, theory, and research (pp. 15-51). Thousand Oaks, CA: Sage Publications.

White, M. (2007). Maps of narrative practice. New York: W. W. Norton \& Co.

Widiger, T. A. (1994). DSM-IV sourcebook. Washington, DC: American Psychiatric Association.

Wiebe, R. (1967). The search for order 1877-1920. New York: Hill and Wang.

Wong, Y., Cheng, S., Choi, S., Ky, K., LeBa, S., Tsang, K., \& Yoo, L. (2003). Deconstructing culture in cultural competence: Dissenting voices from AsianCanadian practitioners. Canadian Social Work Review, 20, 149-167.

Woods, R. (1899). The city wilderness: A settlement study. Boston: Houghton Mifflin.

Young, P. (1949). Scientific social surveys and research $\left(2^{\text {nd }}\right.$ ed.). New York: PrenticeHall. 


\section{Zimbalist, S. (1977). Historic themes and landmarks in social welfare research. New York: Harper \& Row.}

\section{Endnotes}

\footnotetext{
${ }^{1}$ There is good reason why this appears so. The above postmodern practices embrace the philosophical position of social constructionism (De Shazer \& Berg, 1992; Saleebey, 2006a; White, 2007). Being a theory of epistemology, social constructionism attacks the epistemological position of positivism and seeks to replace it. Regarding concerns of ontology, social constructionism's inherent embrace of phenomenology also attacks the correspondence theory of truth that is innately tied to positivism. Positivism, the correspondence theory of truth, and empiricism are the core elements that make up the scientific method.

${ }^{2}$ Darwin's theory met the Kantian criteria of an organizing principle that up until then was lacking in the study of biology - consequently, it served to anchor concepts of human nature within biology and reinforced materialist notions of the person and the environment.

${ }^{3}$ The broad intellectual front where this clash occurs happens over theories of ontology and epistemology. Modernists believe in the correspondence theory of truth—which asserts that the universe is made up of an objective reality. The epistemological theory of positivism offers a method to capture/describe this reality as best as possible through a systematic means of observation (empiricism).
}

Postmodernism embraces the ontological theory of phenomenology in which the universe is made up of phenomena - and phenomena are made up of an existence and an essence. Heidegger (1962/1927) elaborated the postmodern version of phenomenology by asserting the essence of a phenomenon is granted to it by humans' attempt to understand it. This creates the stance that a phenomenon can have multiple realities, depending upon the culture of the individuals observing it. The epistemological theory of social constructionsim offers a method to capture/describe these multiple realities via an examination of how the various essences are socially constructed.

Within the more parochial concerns of social welfare, the ramifications of the above debate have found expression over the concept of culture and concerns for respecting diversity. These ramifications are more fully articulated in the body of this paper. Briefly, if one takes the modernist stance of the universe being comprised of an objective reality, culture is merely a perception of that reality. If one takes the postmodern stance that phenomena are comprised of an existence and essence, culture creates reality.

${ }^{4}$ Further supporting this alternate view of cultural competency is the epistemological theory of social constructionism, and a phenomenological view of ontology: reality as phenomena in which things reveal themselves - that in addition to an existence, phenomena have an essence, which is granted to them by culture.

${ }^{5}$ Hermeneutics-being the study of meaning-is based in axiology (the philosophical branch of values and meaning); thus a hermeneutic inquiry is an axiological endeavor. Values are also based in axiology; this is why the application of social work values generates knowledge. In addition, this is why such an inquiry into human behavior relies upon mimesis-as mimesis is a theory of causality based in axiology. Briefly, mimesis refers to the notion that one has an image of "who I am" and "who I want to be." The image of "who I want to be" guides present actions and informs the "who I am.” For more elaboration on mimesis see Dybicz (2010) and Ricoeur (1984-88). 
This is in contrast to modernist inquiry, which is based in ontology. Newton's causality seeks to explain the movement of objects. The scientific method is an ontological endeavor aimed at uncovering facts that accurately represent reality.

\section{Author's note:}

Address correspondence to: Phillip Dybicz, Keimyung University, Department of Social Welfare, College of Social Science Building, 2800 Dalgubeoldaero, Dalseo-Gu, Daegu

704-701, South Korea. Email: pdybicz@gmail.com 